\title{
SUBSTANTIATION OF THE WORKING WIDTH OF THE TILLAGE IMPLEMENT
}

\author{
Anton Kuvaev¹, Alexey Derepaskin², Ivan Tokarev² \\ ${ }^{1}$ Agricultural Technical Institute, A. Baitursynov Kostanay State University, Baitursynov, 47, 110000 Kostanay, \\ Republic of Kazakhstan \\ ${ }^{2}$ Kostanay branch of Scientific production center of agricultural engineering, LLP, Abay Ave., 34, 110000 Kostanay, \\ Republic of Kazakhstan
}

Link to this article: https://doi.org/10.11118/actaun.2021.002

Received: 6. 3. 2020, Accepted: 14. 12. 2020

To cite this article: KUVAEV ANTON, DEREPASKIN ALEXEY, TOKAREV IVAN. 2021. Substantiation of the Working Width of the Tillage Implement. Acta Universitatis Agriculturae et Silviculturae Mendelianae Brunensis, 69(1): 21-31.

\begin{abstract}
The paper presents the results of theoretical and experimental studies on the substantiation of the working width of the tillage implement for deep tillage. The field experiment was conducted using the «Kirovets» K 744P2 tractor, with an engine power of $257 \mathrm{~kW}$ and an operating mass of $17,000 \mathrm{~kg}$. It was revealed that the optimum working width of the implement should be $4.9-5.6 \mathrm{~m}$ at the travel speed of 2.2-2.0 m/s respectively. This provides a working capacity of 3.9-4.0 ha/h, with the fuel consumption of $13.7-14.1 \mathrm{~kg} / \mathrm{ha}$. The optimization criteria for selecting the optimum working width were the working capacity and specific fuel consumption per hectare. The data obtained based on the experimental studies are comparable with the results of theoretical studies, which indicates the reliability of the developed mathematical model for determining the working width of the agricultural implement.
\end{abstract}

Keywords: tillage implement, working width, draft resistance, travel speed, working capacity

\section{INTRODUCTION}

Deep tillage is an indispensable element of many agricultural technologies. In regions where soils are vulnerable to wind erosion, like Northern Kazakhstan (Akshalov and Kuzhinov, 2017), it is necessary to conduct deep tillage without soil inversion, co-called deep subsurface tillage (Kuvaev, 2018). The major advantage of this tillage method is that it protects the soil against wind erosion by leaving the crop residues on the surface and also decompacts the soil layer. It is especially relevant for soils with heavy mechanical composition and low humus content, which is also typical for Northern Kazakhstan (Baisholanov, 2017). On the other hand, of all the technological operations, deep tillage is the most energy-intensive. One of the ways to reduce the specific energy consumption of agricultural machinery is to increase working capacity. It is known that theoretical field capacity, $C_{t}$ (ha/h), for agricultural machinery is determined by the formula:

$C_{t}=0.36 \times W_{i} \times \mathrm{V}$,

where

$W_{i} \ldots \ldots \ldots . . .$. Working width of the implement, m; $V$.............. travel speed, m/s.

The 0.36 is a conversion constant.

As can be seen from the expression (1), the capacity directly depends on the working width and the travel speed. The travel speed of the implement for deep subsurface tillage is strictly limited by the agronomic requirements (2.0-2.8 m/s) (Tabashnikov, 2010). An increase in speed leads to excessive soil pulverization, as a result, much of the stubble and other crop residues are covered with the soil. In this regard, the most realistic way to increase the 
capacity of the implement is to increase its working width. On the other hand, there is a functional correlation between the working width (along with other factors) and the draft resistance of the tillage implement, formulated by A. P. Goryachkin at the beginning of the XX century (Ceccarelli et al., 2017):

$$
\begin{aligned}
R_{d} & =R_{d_{1}}+R_{d_{2}}+R_{d_{3}}= \\
& =G_{i} \times f+k \times a \times W_{i}+\rho \times a \times W_{i} \times V^{2},
\end{aligned}
$$

$R_{d}$......total draft resistance of the tillage implement, $\mathrm{N}$; $R_{d_{1}} \ldots . .$. resistance, caused by the friction of the working parts of the tillage machine against soil (dead resistance), $\mathrm{N}$;

$R_{d_{2}}$....resistance, caused by the destruction of the soil layer (useful resistance), $\mathrm{N}$;

$R_{d_{3}} \ldots . .$. speed resistance, caused by the movement of the soil layer, $\mathrm{N}$

$G_{i} \ldots . . . .$. Weight of the tillage implement, N;

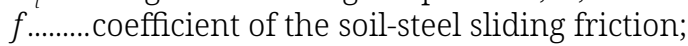

$k$........specific soil resistance, $\mathrm{N} / \mathrm{m}^{2}$;

a.......tilling depth, m;

$\rho$........soil density, $\mathrm{kg} / \mathrm{m}^{3}$.

The reliability of this mathematical model has been repeatedly confirmed by researchers as a result of theoretical and experimental studies (Sharov and Strekalev, 1973; Panov and Vetohin, 2008; Zhalnin, 2019; Croitoru et al., 2016).

The resistance caused by the destruction of the soil layer is at least $70 \%$ of the total draft resistance. According to formula (2), the useful resistance $\left(R_{d_{2}}\right)$ depends on the specific soil resistance, tilling depth, and the working width. Therefore, the three parameters will have the greatest effect on the value of the total draft resistance of the tillage implement. The specific resistance of soil mainly depends on its physical and mechanical properties (moisture, density, hardness, mechanical composition, etc.), which are difficult or impossible to influence. The tilling depth, as well as the travel speed, has a very narrow range of variations, which depends on the agronomic requirements. The working depth of the deep tillage should be set at 5 centimeters below the plow sole layer. In the conditions of Northern Kazakhstan, deep tillage of $a=0.25-0.27 \mathrm{~m}$ depth would be the most effective (Ovchinnikova and Shilov, 2016). In this case, the working width is the parameter that can be used to adjust the value of the draft resistance depending on the traction capabilities of the power unit. This statement is confirmed by the work of other researchers. For example, researchers from Sari Agricultural and Natural Resources University (Moeenifar et al., 2014) found that of all the above-mentioned parameters the working width has the greatest influence on the draft resistance.

In the work (Shirov and Parkhomenko, 2013) the authors, based on the summary of the data obtained from the deep-rippers tests, derived an empirical relationship between the parameters and operation modes of the deep-rippers and physical and mechanical properties of the soil. As a result of the research, the authors concluded that the tilling depth and the working width of the implement have the greatest influence on the value of the draft resistance.

In summary, it can be concluded that of all the factors, the greatest positive correlation is observed between the draft resistance and the working width of the implement. To ensure the maximum performance of the implement, according to formula (1), the working width of the implement should be selected based on the calculations that will take into account the draft resistance created by the tillage implement and traction capabilities of the tractor connected with this implement.

The best option for determining the working width of the tillage implement is the one in which there are traction characteristics of the tractor under consideration, determined for a specific agriculture background. In that case, it is possible to compare the draft resistance of the tillage implement of different working widths with the traction and energy capabilities of the tractor and to determine the possible speed and fuel consumption (University of Nebraska-Lincoln, 2020). However, very often such information is not included in the publicly available tractor specifications. Manufacturers provide a minimum amount of technical information (e.g. effective engine power, fuel consumption per hour, tractor mass). In this case, methods similar to the one presented in Cardei et al. (2017) are used to substantiate the optimum working width. The values of the traction force calculated according to this method take into account only the engine power and do not take into account the operating mass of the tractor, which also affects its traction capabilities. In addition, not all methods of calculation take into account fuel consumption ( $\mathrm{kg} / \mathrm{ha}$ ) at various operating modes, which in turn has a direct impact on economic efficiency.

Cardei (2001) proposed a mathematical model to determine the required tractor traction force, but this work does not show the relationship between power and mass of the tractor.

In the works (Khafizov et al., 2015; Khafizov et al., 2016; Nurmiev et al., 2018), the authors made an attempt to determine the optimal tractor mass for specific tillage implements using developed mathematical models, which consider the influence of tractor mass on the total energy costs. However, the mathematical models in question do not show the relationship between the tractor mass and the traction force it creates. Therefore, the development of a mathematical model for determining the working width of the tillage implement, which will show the relationship between power and mass of the tractor and which will take into account the influence of the mass of the power unit on the traction force it creates, is relevant. 
This study aims to substantiate the working width of the tillage implement. For this purpose, a mathematical model for determining the optimum working width of the tillage implement was developed, which took into account its mass, travel speed, draft resistance, physical and mechanical properties of the soil, and traction capabilities of the tractor. Moreover, the prototype model of the tillage implement was produced and tested in the field to clarify the working width of the implement. The optimization criteria for selecting the optimum working width were the working capacity and the specific fuel consumption per hectare.

\section{MATERIAL AND METHODS}

\section{Methodology of the Theoretical Studies}

To determine the working width of the tillage implement, we consider the rational formula of Goryachkin (2), according to which the weight of the agricultural implement, $G_{i}(\mathrm{~m})$, is represented as follows:

$G_{i}=W_{i} \times M_{s p} \times g$,

$M_{s p}$.......specific mass per meter of implement width, $\mathrm{kg} / \mathrm{m}$;

g ..........gravitational acceleration, $\mathrm{m} / \mathrm{s}^{2}$.

Then equation (2) takes the following form:

$R_{d}=W_{i} \times M_{s p} \times g \times f+k \times a \times W_{i}+\rho \times a \times W_{i} \times V^{2}$.

Equation (4) can be solved with respect to, $W_{i}(\mathrm{~m})$ :

$W_{i}=\frac{R_{d}}{\left(M_{s p} \times g \times f+k \times a+\rho \times a \times V^{2}\right)}$.

The movement of the agricultural implement will be possible if the following criterion is satisfied:

$P_{d b} \times \eta_{r} \geq R_{d}$

$P_{d b}$....drawbar pull (traction force of the power unit), $\mathrm{N}$;

$\eta_{r}$.......coefficient of traction force reserve.

$P_{d b}(\mathrm{~N})$ is determined by the following expression:

$P_{d b}=\frac{N_{d b}}{V} \times 10^{3}$.

$N_{d b} \ldots$. drawbar power (power required to provide the traction force of the tractor), $\mathrm{kW}$.

According to the power balance for the established operating mode of the tractor moving on a horizontal surface and operating without the PTO shaft, the engine power $N_{e}(\mathrm{~kW})$, is used directly to ensure the tractor's traction force $N_{d b}(\mathrm{~kW})$ as well as to overcome energy losses caused by various circumstances:

$N_{e}=N_{d b}+N_{t r}+N_{r}+N_{\text {in }}+N_{\text {climb }}+N_{\delta}+N_{\text {def }}$, where

$N_{t r}$.....power used to overcome friction in tractor transmission components that transmit torque from the engine crankshaft to the driving wheels, kW;

$N_{r}$......power required to overcome internal resistance arising in the tractor's undercarriage (hysteresis loss in rubber wheels of the tractor), $\mathrm{kW}$;

$N_{\text {in }}$.....power needed to change the speed of the tractor (overcoming inertia), kW;

$N_{\text {climb. }}$ power expended on climbing, $\mathrm{kW}$;

$N_{\delta} \ldots . .$. power expended on slipping of the driving wheels, kW;

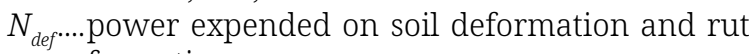
formation.

According to formula (8), $N_{d b}$ (kW) will be determined as the difference between the engine power $N_{e}(\mathrm{~kW})$, and all the mentioned power losses:

$N_{d b}=N_{e}-\left(N_{t r}+N_{r}+N_{i n}+N_{\text {climb }}+N_{\delta}+N_{\text {def }}\right)$.

The $N_{d b}(\mathrm{~kW})$, to $N_{e}(\mathrm{~kW})$, ratio shows which part of the engine power (power spent), taking into account the losses mentioned is converted into the energy (useful) required to provide the traction force of the power unit and is called tractive efficiency, $\eta_{t}$ (Macmillan, 2002):

$\eta_{t}=\frac{N_{d b}}{N_{e}}$.

Consequently $N_{d b}(\mathrm{~kW})$, will be determined by the following formula:

$N_{d b}=N_{e} \times \eta_{t}$,

where

$N_{e}$......engine power, $\mathrm{kW}$;

$\eta_{t}$.......tractive efficiency of the tractor.

The value of $\eta_{t}$ is most accurately determined when conducting the drawbar test of a specific tractor.

Taking into account formulas (6, 7, 10, 11), formula (5) will have the following form:

$W_{i} \leq \frac{N_{e} \times \eta_{t} \times \eta_{r}}{\left(M_{s p} \times g \times f+k \times a+\rho \times a \times V^{2}\right) \times V}$.

Input data for theoretical studies are presented in Tab. I.

The coefficient of the soil-steel sliding friction is determined in accordance with the method described in (Chumakov, 2017).

The value of specific soil resistance is determined experimentally for soils typical for the region under consideration.

The accepted value of soil density ensures the performance of the tillage implements in the most difficult conditions.

The value of tractive efficiency of the tractor is accepted based on the results of acceptance tests of tractors of the "Kirovets" K-744 series, conducted in the Kostanay region (Astafiev et al., 2018). 
I: Input data for the theoretical determination of the working width of the tillage implement in the first approximation

\begin{tabular}{lccc}
\hline \multicolumn{1}{c}{ Index } & Notations & Unit of measure & Index value \\
\hline The specific mass of the implement & $M_{s p}$ & $\mathrm{~kg} / \mathrm{m}$ & $490-600$ \\
Gravitational acceleration & $g$ & $\mathrm{~m} / \mathrm{s}^{2}$ & 9.81 \\
Coefficient of the soil-steel sliding friction & $f$ & - & 0.3 \\
Specific soil resistance & $k$ & $\mathrm{~N} / \mathrm{m}^{2}$ & 36000 \\
Tilling depth & $a$ & $\mathrm{~m}$ & $0.15-0.30$ \\
Soil density & $\rho$ & $\mathrm{kg} / \mathrm{m}^{3}$ & 1500 \\
Working travel speed & $V$ & $\mathrm{~m} / \mathrm{s}$ & $260-280$ \\
Engine power & $N_{e}$ & $\mathrm{~kW}$ & - \\
Tractive efficiency of the tractor & $\eta_{t}$ & - & $0.67-0.70$ \\
Coefficient of traction force reserve & $\eta_{r}$ & 0.95 \\
\hline
\end{tabular}

The necessity of using the coefficient of traction force reserve is explained by the overcoming of climbs and other local obstacles when driving on the field.

Calculations by formula (12) make it possible to determine the range of variations of the working width of the implement for the tractor with known effective engine power. However, it is necessary to make additional calculations to determine the optimum value of the working width of the implement. The optimization criteria for determining the working width of the tillage implement are the working capacity and specific fuel consumption per hectare. Maximum performance with minimum specific fuel consumption should be ensured.

Traction capabilities of the tractor depend not only on the power characteristics of its engine but also on its operating mass (Guskov et al., 1988):

$P_{\text {tan }}=\lambda_{1} \times \varphi \times g \times M_{o p}$,

$P_{\tan }$....tangential traction force of the tractor, $\mathrm{N}$;

$\lambda_{1}$......... coefficient of the load on the driving wheels (for the 4WD tractors $\lambda_{1}=1$ );

$\varphi$.........coefficient of adhesion, allowed under the terms of adhesion and agronomic requirements;

$M_{o p} \ldots$ operating mass of the tractor, $\mathrm{kg}$.

In addition, the tangential traction force $P_{\tan }(\mathrm{N})$, of the tractor upon conditions of the uniform movement on a horizontal surface can be determined using the following formula:

$P_{\text {tan }}=\Delta_{\text {lim }} \times P_{d b}+R_{r l}=\Delta_{\text {lim }} \times P_{d b}+f_{r l} \times g \times M_{o p}$,

$\Delta_{\text {lim }}$........ coefficient of the possible overload;

$R_{r l} \ldots \ldots . . . .$. rolling resistance, $\mathrm{N}$;

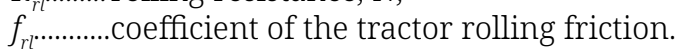

Then, equating formulas (13) and (14) with taking into account formulas (7) and (11), we obtain the expression for determining the required operating mass of the tractor:

$M_{o p}=\frac{\Delta_{\text {lim }} \times N_{e} \times \eta_{t}}{\left(\lambda_{1} \times \varphi-f_{r l}\right) \times g \times V}$.
The specific fuel consumption per hectare is determined in the following sequence. First, we determine the fuel consumption per hour, $Q(\mathrm{~kg} / \mathrm{h})$ :

$Q=\frac{q_{e} \times N_{e}}{1000}$,

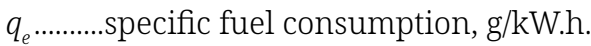

Knowing the fuel consumption per hour and the capacity, we determine the specific fuel consumption per hectare, $Q_{h a}(\mathrm{~kg} / \mathrm{ha})$ :

$Q_{h a}=\frac{Q}{C_{t}}$.

During the calculation procedure, the effective engine power and specific fuel consumption are taken from the condition that the tractor engine in all modes runs at rated speed.

Input data for calculations are presented in Tab. II.

It should be noted that during calculations, the developed tillage implement will be aggregated with the «Kirovets» K-744R2 tractor with the maximum operating mass of $M_{o p}=17,000 \mathrm{~kg}$ (with twin wheels), effective engine power of $N_{e}=257 \mathrm{~kW}$ and specific fuel consumption of $q_{e}=213 \mathrm{~g} / \mathrm{kW}$.h at the nominal speed of the engine crankshaft of 1900 rpm (Peterburgsky Tractorny Zavod, 2019).

The coefficient of the possible overload is taken from the condition of tractor aggregation under the most difficult conditions, in accordance with (Guskov et al., 1988). The coefficient of the load on the driving wheels is taken from the condition of the load redistribution between the front and rear wheels during the tractor work (Guskov et al., 1988). The value of the coefficient of the soil-tractor wheels adhesion is taken based on the maximum allowed slipping of the tractor:

$\varphi=1-\delta$

$\delta$...........tractor slipping

Slipping affects the tractor's energy performance and also has a negative effect on the soil layer 
II: Input data for the final specification of the working width of the tillage implement

\begin{tabular}{|c|c|c|c|}
\hline Coefficient of the possible overload & $\Delta_{\text {lim }}$ & - & $1.3-1.4$ \\
\hline $\begin{array}{l}\text { Coefficient of the adhesion, allowed under the terms of adhesion } \\
\text { and agrotechnical requirements }\end{array}$ & $\varphi$ & & 0.84 \\
\hline
\end{tabular}

- a rut is formed, soil compaction occurs, the growth and development of plants deteriorate. For the 4WD tractors, the maximum slipping is $16 \%$ (Guskov et al., 1988). This is the least desirable operating condition for the tillage implement due to high slipping power losses. The use of the most unfavorable initial conditions in the mathematical model will ensure the operability of the developed tillage implement in the most difficult operating conditions.

The coefficient of the tractor rolling friction was obtained in accordance with (Guskov et al., 1988).

To determine the optimal working width of the tillage implement, the values of $W_{i}$ determined in accordance with formula (12) and corresponding travel speed will be presented in tabular form. We determine the value of drawbar pull, which the tractor can develop at the given travel speed according to formulas (7) and (11), and also we determine the required operating mass of the tractor according to equation (15). Knowing the values of $W_{i}$ and $V$, according to formula (1), we determine the field capacity of the tillage implement. The values of $Q_{h a}$ determined in accordance with formula (17) will also be listed in the table.

The movement of the tillage implement with the considered working width and travel speed can be provided when, firstly, the drawbar pull is greater than the draft resistance created by the implement, according to formula (6), and secondly, the calculated value of the operating mass of the tractor does not exceed the actual one. Taking into account these limitations, the working width of the implement and corresponding travel speed are selected to provide maximum working capacity and minimum fuel consumption per hectare.

\section{Methodology of the Experimental Studies}

To establish the validity of the developed theoretical model for determining the working width of the tillage implement, the field research tests were conducted on the experimental prototype. The general view of the experimental prototype is presented in Fig. 1.

The structural and technological configuration of operating parts, parameters of the loosening and pressing operating tools were determined as a result of previously conducted research (Derepaskin et al., 2017; Kuvaev and Derepaskin, 2018).

To characterize the cultivated soil layer during the period of the research tests, the values of moisture, density, and hardness of the treated soil layer were determined. The measurements were performed in accordance with GOST 20915-2011. The main

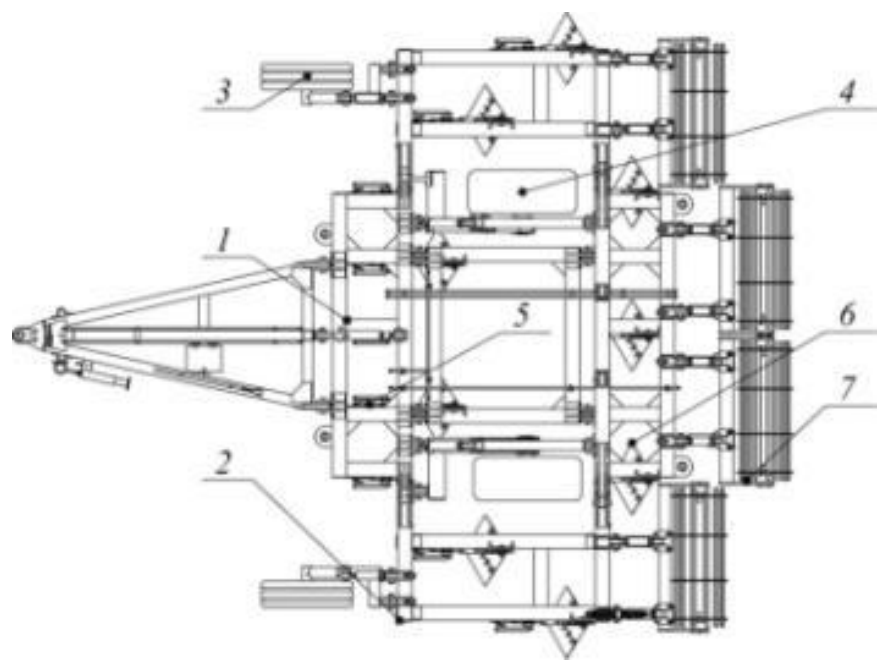

1: General view of the prototype model of the tillage implement

1 - main frame; 2 - side frame; 3 - support wheel; 4 - support and transport wheel; 5 - coulter disc; 6 - subsurface sweep tillage tool;

7 - press wheel 
III: Technical characteristics of the prototype model of the tillage implement

\begin{tabular}{lc}
\hline \multicolumn{1}{c}{ Index } & Index value \\
\hline Mounting method & trailing \\
Working travel speed, $\mathrm{m} / \mathrm{s}$ & $2.0-2.8$ \\
Tilling depth, $\mathrm{m}$ & $0.15-0.30$ \\
Working width, $\mathrm{m}$ & $5.6-6.3$ \\
Number of tillage tools & $7-9$ \\
Mass of the implement, $\mathrm{kg}$ & no more than 3800 \\
\hline
\end{tabular}

technical characteristics of the prototype model of the tillage implement are presented in Tab. III.

The plan for conducting experimental studies to clarify the working width of the agricultural implements is presented in Tab. IV.

The change in the working width of the experimental model occurs due to the change in the number of tillage tools.

As a power unit, the "Kirovets» K-744R2 tractor with an effective engine power of $N_{e}=257-260 \mathrm{~kW}$ was used.

Draft resistance was determined by direct measurement using the device DIN-1U (manufactured by Interpribor, Russian Federation), shown in Fig. 2.

Fuel consumption was measured by a discrete fuel flowmeter IP-197 with a volumetric piston-type dosing mechanism (manufactured by KubNIITIM, Russian Federation). Measurement of speed and slipping of the tractor wheels was made by two impulse 8-cam sensors of wheel rotation. The signals received from the fuel flowmeter and pulse wheel rotation sensors were processed by informationmeasuring system IP-238 (manufactured by KubNIITIM, Russian Federation). The view of these devices is shown in Fig. 3 (connection wires or hoses are not represented in the figure).

Draft resistance, fuel consumption, and travel speed were determined in accordance with GOST R 52777-2007.

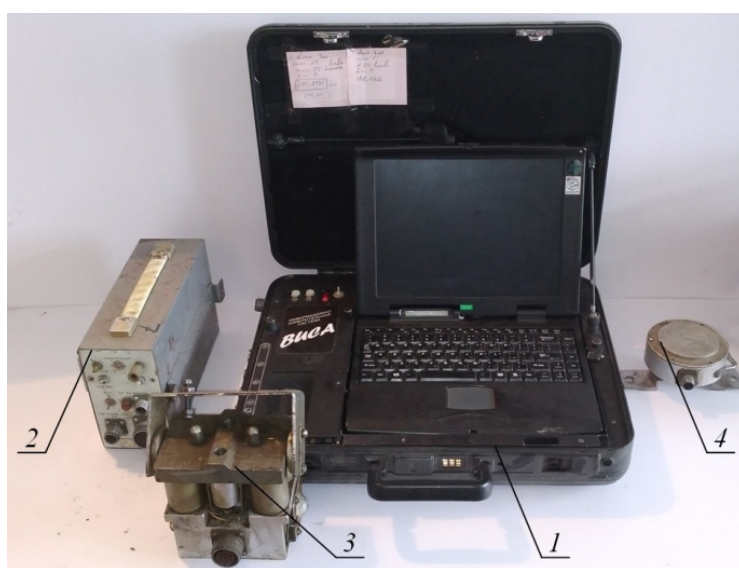

3: General view of the electronic measuring system designed to measure fuel consumption and travel speed

1 - digital metering system IP-238; 2 - electronic discrete signal conversion unit of the fuel flowmeter; 3 - fuel flow sensor; 4 - impulse wheel sensor

IV: Experimental research plan

\begin{tabular}{llll}
\hline \multicolumn{1}{c}{ Variable parameter } & Variation limit & \multicolumn{1}{c}{ Evaluation criterion } \\
\hline Working width of the implement & $4.2 ; 4.9 ; 5.6 ; 6.3$ & & - draft resistance, $\mathrm{kN}$ \\
Working travel speed & $2.0 ; 2.2 ; 2.5 ; 2.8$ & - working capacity, ha/h \\
\hline
\end{tabular}

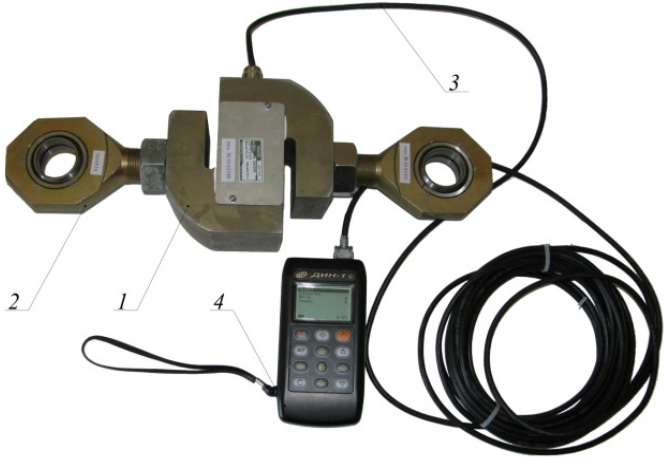

a)

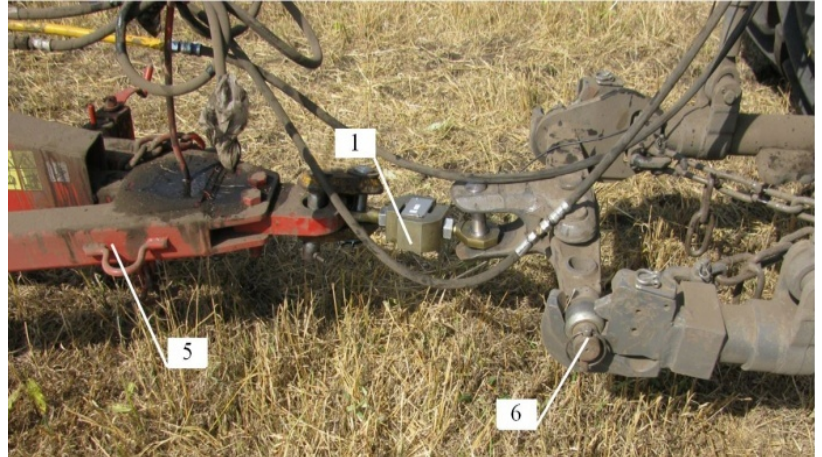

b)

2: Device DIN-1U

1 - force-measuring sensor (strain gauge); 2 - force-transmitting devices; 3 - shielded wire; 4 - electronic unit; 5 - traction coupling device of the experimental model; 6 - tractor mounted system

a) general view of the device; b) view of the device installed between the tractor-mounted system and the traction coupling device of the experimental model 


\section{RESULTS AND DISCUSSION}

\section{Results of the Theoretical Studies}

The working width of the tillage implement was determined in accordance with the methodology of the theoretical studies. The results of the calculations are presented in Fig. 4.

An analysis of the obtained dependence allows us to conclude that, with a constant power of the tractor, an increase in the travel speed and the tilling depth leads to a decrease in the working width due to increased draft resistance.

In Northern Kazakhstan, the maximum depth of the deep tillage typically does not exceed $0.25 \mathrm{~m}$. Let us consider this condition as the most unfavorable and examine the implement's work in more detail (Fig. 5).

According to Fig. 5, at a constant tilling depth of $a=0.25 \mathrm{~m}$, at the agronomically acceptable speed range of $V=2.0-2.8 \mathrm{~m} / \mathrm{s}$ for the engine power of $N_{e}=260 \mathrm{~kW}$, the working width range at the considered speeds will be $=3.7-5.6 \mathrm{~m}$.

We use the obtained data to determine the optimal value of the working width of the tillage implement in accordance with the methodology of the theoretical studies. Since the working width of a single tillage tool is $0.7 \mathrm{~m}$, the working width of the tillage implement should be a multiple of the working width of the single tillage tool.

The results of the calculations are shown in Fig. 6.

The intersection points of the curves $P_{d b}$ and $R_{d}$ characterize the speed mode, which ensures the maximum use of the traction capabilities of the power unit, coupled with the tillage implement under consideration (respectively for each $W_{i}$ value). The intersection of the vertical line drawn from these points with the $M_{o p}$ (calculated) curve characterizes the required tractor mass to achieve the obtained traction force.

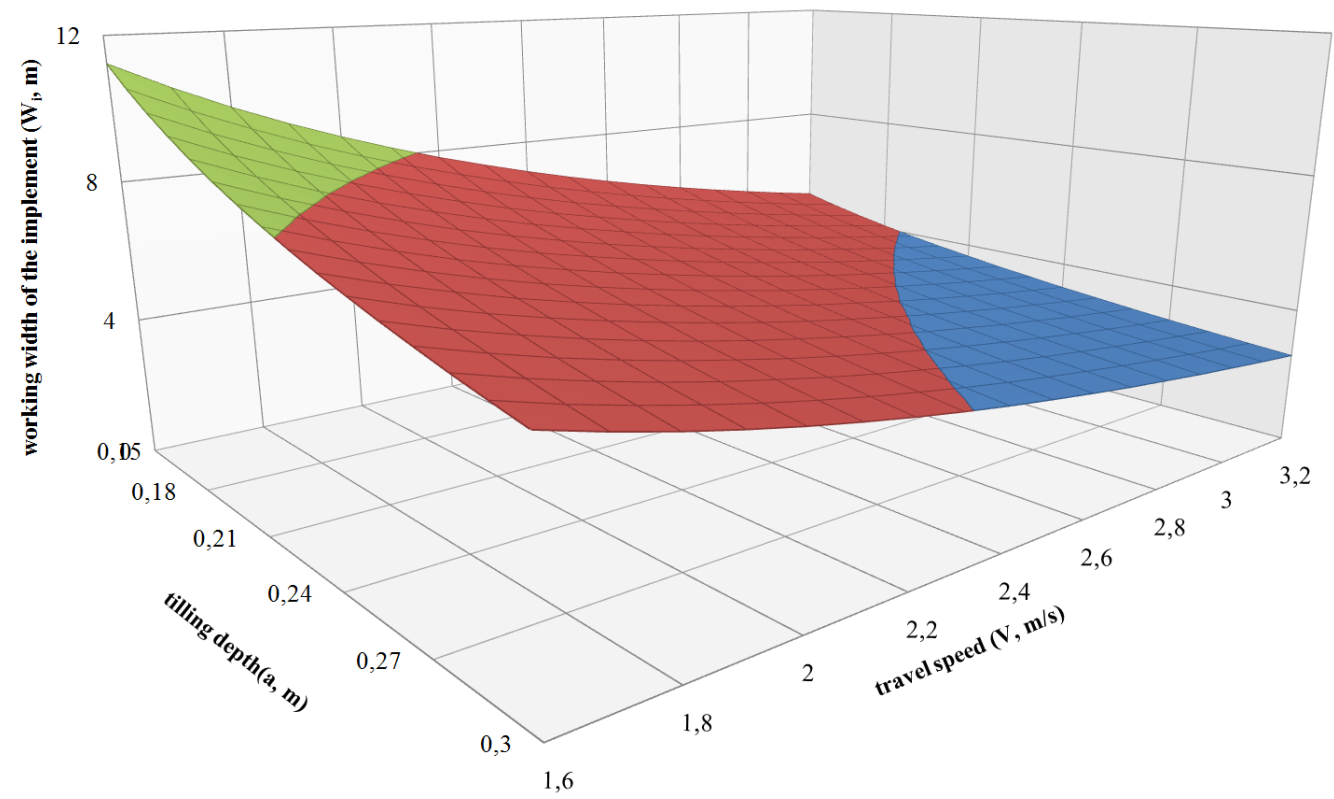

4: The relationship between the working width Wi of the tillage implement, tilling depth a and travel speed $V$ (at $\mathrm{Ne}=260 \mathrm{~kW}$ )

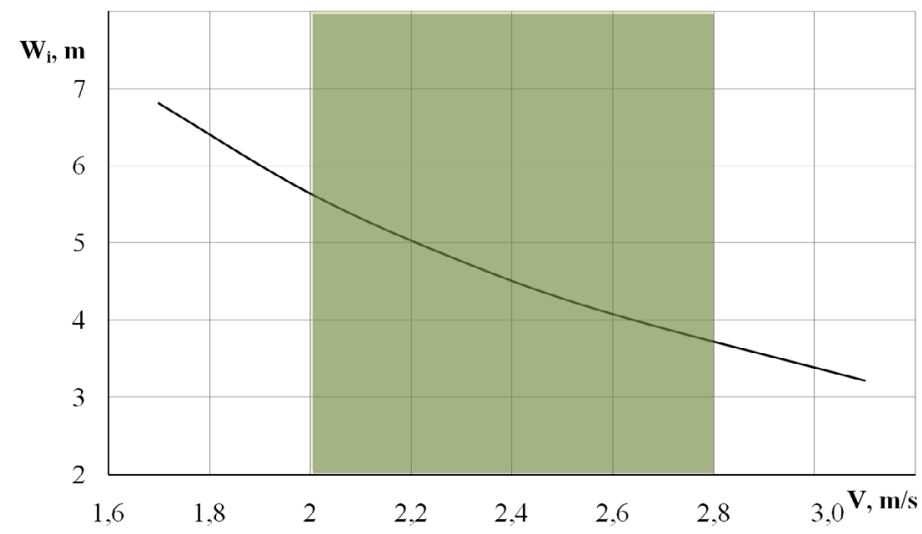

5: The relationship between the working width Wi of the tillage implement and the travel speed $V$ (at $a=0.25 \mathrm{~m}$ and $\mathrm{Ne}=260 \mathrm{~kW}$ ) 


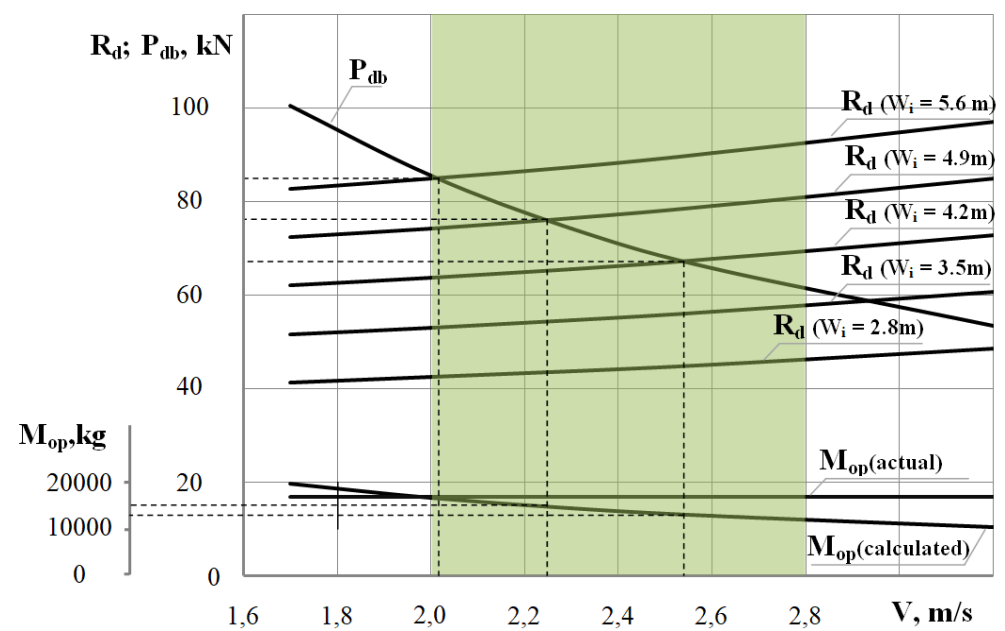

6: Effect of travel speed $(\mathrm{V}, \mathrm{m} / \mathrm{s})$ and working width $(W i, \mathrm{~m})$ of the tillage implement on the draft resistance $(R d, k N)$ of the tillage implement. Effect of travel speed $(V, m / s)$ on drawbar pull $(P d b, k N)$ of the power unit and required operating mass (Mop, calculated, $\mathrm{kg}$ ).

$\mathrm{V}$ : Results of the theoretical studies on the substantiation of the working width of the tillage implement

\begin{tabular}{lcccccc}
\hline$W_{i}(\mathrm{~m})$ & $V(\mathrm{~m} / \mathrm{s})$ & $R_{d}(\mathrm{kN})$ & $P_{b d}(\mathrm{kN})$ & $M_{o p}\left(\mathrm{~kg} .10^{3}\right)$ & $C_{t}(\mathrm{ha} / \mathrm{h})$ & $Q_{h a}(\mathrm{~kg} / \mathrm{ha})$ \\
\hline 4.2 & 2.5 & 66.53 & 67.81 & 13.24 & 3.81 & 14.37 \\
4.9 & 2.2 & 75.41 & 75.96 & 14.83 & 3.97 & 13.79 \\
5.6 & 2.0 & 84.10 & 85.45 & 16.69 & 4.07 & 13.45 \\
\hline
\end{tabular}

There are three intersection points of $P_{d b}$ and $R_{d}$ curves in the $2.0-2.8 \mathrm{~m} / \mathrm{s}$ speed range. The values of $W_{i}, V, P_{d b}, R_{d}$ and $M_{o p}$ corresponding to these points, as well as $C_{t}$ and $Q_{h a}$ values, calculated according to formulas (1) and (17) are presented in Tab. V.

An analysis of the results shows that in the conditions under consideration, maximum working capacity with minimum specific fuel consumption is provided at $W_{i}=4.9-5.6 \mathrm{~m}$ and $V=2.0-2.3 \mathrm{~m} / \mathrm{s}$. At this speed, the drawbar pull is strong enough to overcome the draft resistance produced by the implement $\left(P_{d b}=75.96 \mathrm{kN}, R_{d}=75.41 \mathrm{kN}\right.$, and $P_{d b}=85.45 \mathrm{kN}, R_{d}=84.10 \mathrm{kN}$ respectively at $V=2.2 \mathrm{~m} / \mathrm{s}$ and $V=2.0 \mathrm{~m} / \mathrm{s}$ ), and the calculated value of the operating mass required to create the traction force does not exceed the actual one.

VI: Moisture, hardness and density of soil layers

\begin{tabular}{lccc}
\hline VI: Moisture, hardness and density of soil layers & Indicator \\
\cline { 2 - 4 } Soil layer, $\mathrm{m}$ & Moisture (\%) & Hardness (MPa) & Density $\left(\mathrm{kg} / \mathrm{m}^{3}\right)$ \\
\hline $0-0.05$ & 14.10 & 1.10 & 1100 \\
$0.05-0.10$ & 14.50 & 3.00 & 1200 \\
$0.10-0.15$ & 16.60 & 4.70 & 1300 \\
$0.15-0.20$ & 20.40 & 5.50 & 1300 \\
$0.20-0.25$ & 18.90 & 6.10 & 1400 \\
$0.25-0.30$ & 17.60 & 7.10 & 1400 \\
\hline
\end{tabular}

Thus, based on the theoretical studies carried out to substantiate the working width of the tillage implement for the «Kirovets» K-744R2 tractor with the maximum operating mass of $M_{o n}=17,000 \mathrm{~kg}$ and effective engine power of $N_{e}=257 \mathrm{~kW}$, it was revealed that the optimum working width should be $W_{i}=4.9-5.6 \mathrm{~m}$ at the travel speed of $V \approx 2.2-2.0 \mathrm{~m} / \mathrm{s}$ respectively.

The reliability of the results of the theoretical studies was verified during experimental studies.

\section{Results of the Experimental Studies}

Experimental studies of the prototype model of the tillage implement were carried out in JSC «Zarya» of the Mendykarinsky district, Kostanay region, Republic of Kazakhstan, in grain crop stubble field. The soil type is classified as black earth (chernozem) 


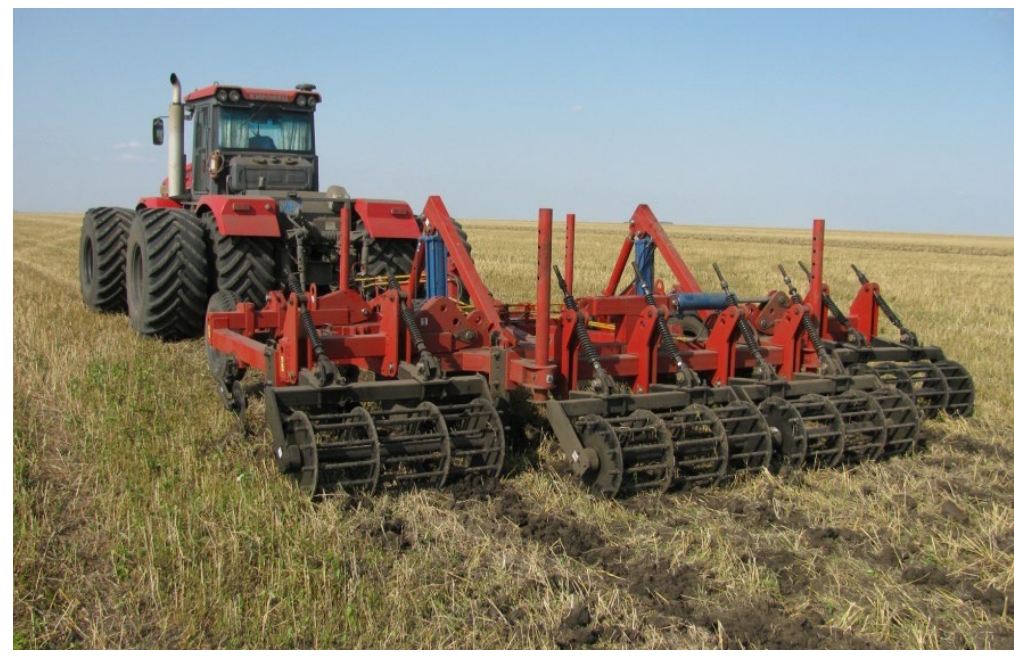

7: Experimental model of the tillage implement aggregated with the tractor «Kirovets» K-744P2

VII: Results of the experimental studies on the substantiation of the working width of the tillage implement

\begin{tabular}{lcccc}
\hline$W_{i}(\mathrm{~m})$ & $V(\mathrm{~m} / \mathrm{s})$ & $R_{d}(\mathrm{kN})$ & $C_{t}(\mathrm{ha} / \mathrm{h})$ & $Q_{h a}(\mathrm{~kg} / \mathrm{ha})$ \\
\hline \multirow{3}{*}{4.2} & 2.0 & 63.0 & 2.9 & 18.8 \\
& 2.2 & 64.7 & 3.4 & 17.2 \\
\hline \multirow{2}{*}{4.9} & 2.5 & 67.1 & 3.8 & 14.6 \\
\hline 5.6 & 2.0 & 70.1 & 3.4 & 15.8 \\
\hline 6.3 & 2.2 & 74.8 & 3.9 & 14.1 \\
\hline
\end{tabular}

and by its mechanical composition as loam. The condition of the soil layer during the studies was characterized by the following indicators given in Tab. VI.

The specific tractive resistance of the soil in the cultivated area was $38 \mathrm{kN} / \mathrm{m}^{2}$.

The view of the experimental model of the tillage implement aggregated with the tractor «Kirovets» K-744P2 is presented in Fig. 7.

Experimental studies were carried out in accordance with the research methodology. The results of experimental studies are presented in Tab. VII.

Traction capabilities and operating mass of the tractor made it possible to overcome the draft resistance created by the implement with the working widths of $W_{i}=4.2 \mathrm{~m}(\max V=2.5 \mathrm{~m} / \mathrm{s})$, $W_{i}=4.9 \mathrm{~m}(\max V=2.2 \mathrm{~m} / \mathrm{s})$ and $W_{i}=5.6 \mathrm{~m}(\max$ $V=2.0 \mathrm{~m} / \mathrm{s}$ ). In doing so, the engine crankshaft speed corresponded to the nominal speed (1900 rpm), and the value of slipping did not exceed the limit value. A further increase in speed was not possible due to increased slipping of the tractor's driving wheels by more than $16 \%$ and a drop in the engine crankshaft speed below nominal. For the same reason, it was not possible to provide steady movement of the tractor at $W_{i}=6.3 \mathrm{~m}$.

The data obtained during the experimental studies are comparable with the results of the theoretical studies, which indicates the reliability of the developed mathematical model for determining the working width of the tillage implement.

Summarizing the information presented above, it can be concluded that with the tractor under consideration, the optimum working width of the implement should be $W_{i}=4.9-5.6 \mathrm{~m}$ at the travel speed of $V=2.2-2.0 \mathrm{~m} / \mathrm{s}$ respectively. This ensures the capacity of $C_{t}=3.9-4.0 \mathrm{ha} / \mathrm{h}$ with the fuel consumption per hectare of $Q_{h a}=13.7-14.1 \mathrm{~kg} / \mathrm{ha}$.

\section{CONCLUSION}

An analysis of the scientific literature showed that the existing method for determining the working width of tillage implements is based on comparing the draft resistance created by the implement (at different working widths) with the traction capabilities of a particular tractor, obtained by an 
experimental (traction characteristic of a tractor) or calculated way. The traction characteristic of a tractor provides sufficient accuracy to determine the optimum working width of the tillage implement. However, very often such information is not included in the publicly available tractor specifications. The available methods do not take into account the operating mass of the tractor when determining the traction capabilities of the tractor. As a result, the calculated value for the tractor's traction force may be overestimated.

During the theoretical studies, a mathematical model for determining the optimum working width of the tillage implement to the tractor under consideration was developed, which took into account its mass, travel speed and the draft resistance it creates, the physical and mechanical characteristics of the soil, as well as the traction capabilities of the tractor. The optimization criteria for selecting the optimum working width were the working capacity and specific fuel consumption per hectare. The proposed mathematical model can be used to substantiate the structural parameters of the tillage implements, specifically to determine its working width.

The data obtained during the experimental studies were confirmed during the field experiment, which indicates the reliability of the developed mathematical model for determining the working width of the agricultural implement.

It was found that with the considered tractor with an engine power of $257 \mathrm{~kW}$ and an operating mass of $17,000 \mathrm{~kg}$, the optimum working width of the implement at the tilling depth of $0.25 \mathrm{~m}$ should be $4.9-5.6 \mathrm{~m}$ at the travel speed of $2.2-2.0 \mathrm{~m} / \mathrm{s}$ respectively. This provides the capacity of $3.9-4.0 \mathrm{ha} / \mathrm{h}$, with the fuel consumption of $13.7-14.1 \mathrm{~kg} / \mathrm{ha}$.

\section{Acknowledgements}

The authors would like to thank the administration of the Kostanay branch of the "Scientific Production Center of Agricultural Engineering” for the assistance provided during the experimental studies.

\section{REFERENCES}

AKSHALOV, K. A. and KUZHINOV, M. B. 2017. Principles of land use in Kazakhstan at the present stage: state, prospects [in Russian: Приниипы землепользования в Казахстане на современном этапе: состояние, перспективы]. In: Nature protection and regional development: harmony and conflicts (by the year of ecology in Russia). Materials of the international scientific-practical conference. 1-5 October. Orenburg: Steppe Institute of the Ural Branch of the Russian Academy of Sciences, pp. 100-104.

ASTAFIEV, V. L., OKUNEV, G. A., SHEPELEV, S. D. and KUZNETSOV, N. A. 2018. Machine Use Design in Agriculture [in Russian: Проектирование машиноиспользования в земледелии]. A textbook for university students. Kostanay: New line media.

BAISHOLANOV, S. S. 2017. Agroclimatic Resources of the Kostanay Region [in Russian: Агроклиматические ресурсы Костанайской области]. Applied Scientific Reference Book. Astana: Institute of Geography of the Ministry of Education and Science of the Republic of Kazakhstan.

CÂRDEI, P. 2001. Researches regarding the Motion Equation of the Tractor in Aggregation with the Machines for Soil Processing. [Online]. Available at: https://www.researchgate.net/publication/314154209_ Researches_regarding_the_Motion_Equation_of_the_Tractor_in_Aggregation_with_the_Machines_ for_Soil_Processing [Accessed: 2020, December 15].

CARDEI, P., MATACHE, M. and NUTESCU, C. 2017. Optimum working conditions for variable width ploughs. [Online]. Available at: https://www.researchgate.net/ publication/318983573_Optimum_ working_conditions_for_variable_width_ploughs [Accessed: 2020, December 15].

CECCARELLI, M., CIGOLA, M. and RECINTO, G. 2017. New Activities For Cultural Heritage. In: Proceedings of the International Conference Heritagebot 2017. Cham: Springer International Publishing, pp. 1-11.

CHUMAKOV, V. G. 2017. Technological Basics of Mechanical Soil Treatment [in Russian: Технологические основы механической обработки почвы]. Methodological Instructions for Performing Laboratory and Practical Training of Postgraduate Students. Kurgan: Kurgan SAA.

CROITORU, S., VLADUT, V., MARIN, E., MATACHE, M. and DUMITRU, I. 2016. Determination of subsoiler traction force influenced by different working depth and velocity. Jelgava: Engineering for rural development.

DEREPASKIN, A. I., KUVAEV, A. N. and TOKAREV, I. V. 2017. Justification of parameters of the roller organization for the main processing of seal soils [in Russian: Обоснование параметров пруткового катка к орудию для основной обработки уплотненных почв]. International agroengineering, Scientific-technical journal, 2: 66-72. 
GUSKOV, V. V., VELEV, N. N., ATAMANOV, Y. E., BOCHAROV, N. F., KSENEVICH, I. P. and SOLONSKIY, A. S. 1988. Tractors. Theory [in Russian: Тракторы. Теория.] Textbook for university students. Moscow: Mashinostroenie.

KHAFIZOV, K. A. and KHAFIZOV, R. N. 2015. Energy optimization method of main parameters of tractors. Vestnik of the Kazan State Agrarian University, 1(35): 75-81.

KHAFIZOV, K. A. and KHAFIZOV, R. N. 2016. Results of multivariate experiment to determine dependence of the maximum pressure of tractor wheels on the soil from tractor's parameters and physical and mechanical properties of soil. Statistical analysis. Vestnik of the Kazan State Agrarian University, 4(42): 94-98.

KUVAEV, A. N. 2018. Basic processing of stubble fields in northern grain sowing regions of Kazakhstan and modern tools for its implementation [in Russian: Основная обработка стерневых полей северных зерносеющих регионов Казахстана и современные орудия для её выполнения]. Multidisciplinary scientific journal 3i: intellect, idea, innovation, 2: 57-64.

KUVAEV, A. N. and DEREPASKIN, A. I. 2018. The comparative evaluation of the constructive schemes of the subsurface plow for primary tillage of the consolidated soils [in Russian: Сравнительная оценка конструктивных схем плоскореза-глубокорыхлителя для основной обработки уплотненных почв]. In: Ways of implementation of the Federal Scientific and Technical Program of Agricultural Development for 2017-2025: Proceedings of the International Scientific and Practical Conference. 19-20 April, Kurgan, pp. 1039-1043.

MACMILLAN, R. H. 2002. The mechanics of tractor-implement performance: theory and worked examples. A textbook for students and engineers. Melbourne, Australia: University of Melbourne.

MOEENIFAR, A., MOUSAVI-SEYEDI, S. R. and KALANTARI, D. 2014. Influence of tillage depth, penetration angle and forward speed on the soil/thin-blade interaction force. Agric Eng Int: CIGR Journal, 16(1): 69-74.

NURMIEV, A., KHAFIZOV, C., KHAFIZOV, R. and ZIGANSHIN, B. 2018. Optimization of main parameters of tractor working with soil-processing implement. In: Engineering for rural development. Materials of the international scientific conference. Jelgava, Latvia, pp. 161-167.

OVCHINNIKOVA, K. P. and SHILOV, M. P. 2016. Influence of methods of autumn treatment of common chernozems on the differentiation of arable layer in the conditions of northern Kazakhstan [in Russian: Влияние приемов осенней обработки черноземов обыкновенных на дифференциацию пахотного слоя в условиях северного Казахстана]. Multidisciplinary scientific journal 3i: intellect, idea, innovation, 4: 57-64.

PANOV, I. M. and VETOHIN, V. I. 2008. Current state and prospects of agricultural mechanics development in the light of V. P. Goryachkin's works [in Russian: Современное состояние и перспективы развития земледельческой механики в свете трудов В.П. Горячкина]. Vestnik of FGOU VPO MGAU, 2: 9-14.

PETERBURGSKY TRACTORNY ZAVOD. 2019. Agricultural tractors. Peterburgsky Tractorny Zavod. [Online]. Available at: http://kirovets-ptz.com [Accessed: 2020, December 15].

SHAROV, M. N. and STREKALEV, V. A. 1973. Mathematical model for determining the components of the cultivator's draft resistance [in Russian: Математическая модель для определения составляющих тягового сопротивления культиватора]. In: Analysis and evaluation of the efficiency of agricultural machinery structures. Collection of scientific papers. Rostov-on-Don, Russian Federation: RISHM, pp. 74-81.

SHIROV, V. N. and PARKHOMENKO, G. G. 2013. Aprioristic determination of traction resistance of the deep-ripper by methods of the dimensions and similarity theory [in Russian: Априорное определение тягового сопротивления глубокорыхлителя методами теории размерностей и подобия]. Don Agrarian Science Bulletin, 1(21): 28-37.

TABASHNIKOV, A. T. 2010. System of criteria for quality, reliability, economic efficiency of agricultural machinery. Instructional-methodical edition. Moscow: Rosinformagrotech.

UNIVERSITY OF NEBRASKA-LINCOLN. 2020. Test Reports. Nebraska Tractor Test Laboratory. [Online]. Available at: https://tractortestlab.unl.edu/testreports [Accessed: 2020, December 15].

ZHALNIN, E. 2019. Goryachkin's rational equation in the differential form. V.P. E3S Web of Conferences, 126: 1-4.

\section{Contact information}

Anton Kuvaev: 1989_antoxa_30@mail.ru

Alexey Derepaskin: celinnii@mail.ru

Ivan Tokarev: usilok5kvt@mail.ru 
